\title{
PERAN MEDIASI KEPUASAN KERJA PADA PENGARUH WORK- FAMILY CONFLICT TERHADAP TURNOVER INTENTION KUTABEX BEACH FRONT
}

\author{
Ni Putu Mia Silvyana ${ }^{1}$ \\ I Made Artha Wibawa ${ }^{2}$ \\ ${ }^{1}$ Fakultas Ekonomi dan Bisnis Universitas Udayana, Bali, Indonesia \\ email:msilvyana@yahoo.co.id
}

\begin{abstract}
ABSTRAK
Penelitian dilakukan di Kutabex Beach Front. Jumlah sampel yang digunakan sebanyak 56 orang karyawan wanita, dengan teknik purposive random sampling. Pengumpulan data diperoleh dari wawancara dan penyebaran kuesioner. Teknik analisis data yang digunakan adalah structural equation model (SEM) menggunakan variance based dengan partial least square (PLS) 3.0 serta variance accounted for (VAF) untuk menguji variabel mediasi. Hasil penelitian ini menemukan bahwa work-family conflict berpengaruh negatif signifikan terhadap kepuasan kerja. Workfamily conflict berpengaruh positif signifikan terhadap turnover intention. Kepuasan kerja berpengaruh negatif signifikan terhadap turnover intention. Kepuasan kerja berperan sebagai mediasi secara parsial pada pengaruh work-family conflict terhadap turnover intention. Implikasi penelitian ini diharapkan dapat menurunkan work-family conflict sehingga karyawan dapat merasakan kepuasan kerja dan tidak memiliki keinginan untuk keluar dari perusahaan. Keterbatasan penelitian ini hanya dapat diterapkan di lingkungan Kutabex Beach Front.

Kata kunci : kepuasan kerja, work-family conflict, turnover intention
\end{abstract}

\begin{abstract}
The research was conducted at Kutabex Beach Front. The number of samples used was 56 female employees, with a purposive random sampling technique. Data collection was obtained from interviews and questionnaires. The data analysis technique used is structural equation model (SEM) using variance based with partial least square (PLS) 3.0 and variance accounted for $(V A F)$ to test mediating variables. The results of this study found that work-family conflict had a significant negative effect on job satisfaction. Work-family conflict has a significant positive effect on turnover intention. Job satisfaction has a significant negative effect on turnover intention. Job satisfaction acts as a partial mediation on the effect of work-family conflict on turnover intention. The implications of this study are expected to reduce work-family conflict so that employees can feel job satisfaction and have no desire to leave the company. The limitations of this study can only be applied in the Kutabex Beach Front environment.

Keywords: job satisfaction, work-family conflict, turnover intention
\end{abstract}




\section{PENDAHULUAN}

Dewasa ini, sektor pariwisata yang terus berkembang memberikan peluang yang besar atas pertumbuhan ekonomi di Indonesia, khususnya di Bali. Perkembangan pariwisata di Bali salah satunya ditandai dengan munculnya hotelhotel yang menawarkan berbagai fasilitas dan layanan yang dapat menarik minat konsumen. Bisnis perhotelan di Bali merupakan usaha yang menjanjikan apabila dapat dikelola dengan baik.

Kemajuan suatu perusahaan sangat bergantung pada sumber daya manusia (SDM) yang andal khususnya pada industri jasa perhotelan, hotel merupakan perusahaan jasa yang mengedepankan kualitas SDM demi tercapainya tujuan perusahaan (Ksama \& Wibawa, 2016). Selain modal yang menjadi unsur penting dalam suatu perusahaan, karyawan juga merupakan unsur penting lainnya yang harus dimiliki oleh perusahaan, karena tanpa adanya karyawan dalam suatu perusahaan maka perusahaan tidak akan mampu dalam mencapai tujuan yang diinginkan. (Hasibuan, 2014: p. 9) menyatakan salah satu yang harus diperhatikan dalam perusahaan agar mampu berjalan sesuai dengan tujuan yang diharapkan oleh manajemen adalah seorang karyawan, karena dengan diberikannya dukungan dan pengelolaan yang baik, maka karyawan akan merasakan kepuasan dalam bekerja dan perusahaan akan menjadikan hal ini sebagai umpan balik untuk mencapai tujuan perusahaan. Manajemen sumber daya manusia (SDM) memiliki peranan yang penting dalam suatu perusahaan untuk mengelola karyawan seperti mempertahankan karyawan yang memiliki potensi agar dapat bertahan di perusahaan dan tidak memiliki keinginan untuk berpindah (turnover intention).

Tett dan Meyer (1993) mengemukakan turnover intention merupakan niat individu yang dilakukan secara sadar serta disengaja untuk keluar dari perusahaan tempat karyawan tersebut bekerja. Turnover mengarah pada kenyataan akhir yang dihadapi suatu organisasi berupa jumlah karyawan yang meninggalkan organisasi pada periode tertentu, sedangkan keinginan karyawan untuk berpindah (turnover intention) mengacu pada hasil evaluasi individu mengenai kelanjutan hubungan dengan organisasi yang belum diwujudkan dalam tindakan pasti untuk meninggalkan organisasi (Tariana \& Wibawa, 2016).

Tingginya tingkat turnover intention telah menjadi masalah serius bagi banyak perusahaan, bahkan beberapa perusahaan mengalami frustasi ketika mengetahui proses rekrutmen yang telah berhasil menjaring staf yang berkualitas memiliki keinginan untuk bekerja diperusahaan lain (Hutagalung \& Artha, 2018). Perusahaan dapat mengurangi tingkat turnover intention tetapi tidak dapat menghentikan atau menghilangkannya, tingkat turnover yang tinggi tidak baik bagi perusahaan yang bersangkutan sehingga perusahaan mencoba untuk mempertahankan karyawan dan menghemat biaya perusahaan (Saeed et al., 2014). Turnover intention dikatakan mahal karena menimbulkan banyak biaya seperti, biaya perekrutan, biaya pelatihan, dan biaya lainnya (M. A. S. Khan \& Du, 2014). Salah satu penyebab karyawan mengambil keputusan untuk keluar dari organisasi adalah rendahnya kepuasan kerja (Kristanto et al., 2014). Meskipun pergantian karyawan didorong oleh alasan yang berbeda, kondisi kerja yang penuh tekanan dianggap sebagai salah satu faktor paling umum dalam mendorong karyawan keluar dari organisasi (Afsar \& Rehman, 2017). 
Kepuasan kerja adalah keadaan emosi yang menyenangkan atau positif, yang dihasilkan dari penilaian pekerjaan atau pengalaman kerja seseorang. Dalam istilah yang paling sederhana, kepuasan kerja adalah variabel sikap yang menggambarkan sejauh mana orang menyukai atau tidak menyukai pekerjaan mereka (Ozbag \& Ceyhun, 2014). Jika karyawan merasa tidak puas akan pekerjaannya maka karyawan tersebut akan mengalami penurunan kinerja. Kepuasan kerja yang baik dapat mendorong kinerja karyawan tersebut untuk melakukan pekerjaan dengan lebih baik dan dapat meningkatkan produktifitas perusahaan serta membuat karyawan tetap bertahan di perusahaan tersebut (Saputra \& Wibawa, 2018). Karyawan akan merasa senang dan nyaman apabila kondisi lingkungan sesuai dengan yang diharapkan dan diberikan penghargaan atas kontribusi yang telah diberikan oleh karyawan (Dewi \& Wibawa, 2016).

Adapun penyebab lain turnover intention adalah work-family conflict, saat ini work-family conflict dianggap sebagai isu penting dalam dunia bisnis (Burke \& ElKot, 2010). Work-family conflict dapat terjadi pada pria maupun wanita. Workfamily conflict berhubungan lebih kuat dengan depresi dan kecemasan yang diderita oleh wanita dibandingkan pria (Roboth, 2015). Wanita karier adalah kaum yang rentan memiliki masalah peran ganda, mengingat wanita karier yang sudah berkeluarga menjalani dua peran krusial. Bekal keterampilan meniti karier, membuat wanita bisa menjadi seorang yang unggul dan dibutuhkan oleh perusahaan, namun tidak sedikit dari mereka gagal dalam membangun karier dikarenakan belum mampu menyeimbangkan peran sebagai pembangun keluarga dan seorang pekerja, hal ini menyebabkan suatu konflik yang disebut konflik pekerjaan-keluarga (work-family conflict) (Susanto, 2010).

Multi peran dalam kehidupan wanita modern dengan segala aktivitas yang padat harus disiasati dengan mampu membagi waktu untuk karier dan kehidupan pribadi. Perbedaan sejarah, struktur, budaya dan adat istiadat yang dimiliki oleh suatu daerah, menuntut wanita melaksanakan peran yang berbeda pula bahkan lebih kompleks (Yeyen, 2017). Wanita di abad 21 menurut (Moser, 1989), tidak hanya menjalankan dua peran tetapi tiga peran sekaligus. Ketiga peran tersebut meliputi peran keluarga, peran ekonomi, dan peran sosial atau yang disebut dengan triple roles. Tuntutan peran keluarga yang berlebihan sering berdampak pada peran dalam dunia kerja. Work-family conflict adalah konflik yang terjadi karena adanya ketidakseimbangan peran antara tanggung jawab didalam keluarga dengan di tempat kerja. Work-family conflict sering dikaitkan dengan konsekuensi negatif, baik dalam organisasi maupun keluarga (Erkmen \& Esen, 2014).

Kutabex Beach Front Hotel merupakan hotel bintang 3 yang menawarkan beberapa fasilitas dan layanan hotel seperti spa, karaoke, coffee shop, conference room, banquet hall, dan kolam renang outdoor. Wawancara awal yang dilakukan peneliti terhadap 10 orang karyawan wanita yang telah resign pada Kutabex Beach Front Hotel, mendapatkan hasil bahwa terdapat beberapa karyawan yang memiliki niat untuk meninggalkan perusahaan karena keinginannya sendiri. Karyawan yang memiliki niat untuk meninggalkan perusahaan karena niatnya sendiri, dikarenakan karyawan tersebut berpindah tempat tinggal yang jauh dari hotel tempat ia bekerja ataupun telah mendapatkan kesempatan kerja yang lebih baik ditempat lain. 
Terdapat juga karyawan wanita yang memiliki niat untuk meninggalkan perusahaan dikarenakan kesulitan dalam membagi waktu antara keluarga dan pekerjaan seperti tidak memiliki waktu bersama anak dan suami. Pekerjaan akhir tahun ketika hotel ramai akan pengunjung karyawan wanita cenderung lebih banyak menghabiskan waktu di hotel dibandingkan dengan keluarganya.

Beberapa karyawan wanita juga memiliki keinginan keluar dari perusahaan dikarenakan beban kerja yang tidak sesuai dengan keahlian karyawan tersebut, gaji yang tidak sepadan dengan kinerja karyawan, kurangnya kesempatan dari karyawan wanita untuk memperoleh kenaikan jabatan, kurangnya bantuan dari pimpinan saat karyawan mengalami kesulitan kerja dan hubungan kurang baik antara karyawan wanita dengan rekan kerjanya seperti menukar shift pekerjaan. Alasan peneliti memilih karyawan wanita Kutabex untuk diteliti dikarenakan persentase turnover karyawan wanita setiap tahunnya tinggi melebihi $10 \%$ dibandingkan persentase turnover karyawan pria yang dibawah $10 \%$ dapat dilihat Tabel 1 . Selain itu peneliti ingin mengetahui apa penyebab tingginya turnover karyawan wanita di Kutabex ini, apakah ada hubungannya dengan variabel work-family conflict dan variabel kepuasan kerja.

Setiawan dan Brian (2013) turnover karyawan dikatakan normal berkisar 5 $10 \%$ per tahun, dikatakan tinggi apabila lebih dari 10\%. Berdasarkan Tabel 1 pada tahun 2017 tingkat turnover karyawan wanita Kutabex Beach Front Hotel mencapai $15,9 \%$ meningkat dari tahun sebelumnya, sedangkan tingkat turnover karyawan pria mencapai 6,8\%. Dari data tersebut dapat disimpulkan bahwa tingkat turnover karyawan wanita lebih tinggi dibandingkan tingkat turnover karyawan pria, dengan tingginya tingkat turnover karyawan wanita melebihi $10 \%$ maka dapat menimbulkan masalah pada perusahaan.

Adapun data turnover karyawan wanita dan karyawan pria Kutabex Beach Front Hotel pada tahun 2015-2017 pada Tabel 1.

Tabel 1.

Data Turnover karyawan wanita dan karyawan pria Kutabex Beach Front Hotel Pada Tahun 2015-2017

\begin{tabular}{|c|c|c|c|c|c|c|}
\hline & Tahun & $\begin{array}{c}\text { Jumlah } \\
\text { Karyawan } \\
\text { Awal } \\
\text { Tahun } \\
\text { (Orang) } \\
\text { (1) }\end{array}$ & $\begin{array}{c}\text { Jumlah } \\
\text { Karyawan } \\
\text { Akhir } \\
\text { Tahun } \\
\text { (Orang) } \\
\text { (2) }\end{array}$ & $\begin{array}{c}\text { Rata-rata } \\
\text { Jumlah } \\
\text { Karya- } \\
\text { wan } \\
\text { (3) }=(1)+ \\
\text { (2):2 }\end{array}$ & $\begin{array}{l}\text { Karya- } \\
\text { wan } \\
\text { Keluar } \\
\text { (orang) } \\
\text { (4) }\end{array}$ & $\begin{array}{c}\begin{array}{c}\text { Karyawan } \\
\text { Keluar } \\
(\%)\end{array} \\
(5)=(4):(3) \times \\
100 \%\end{array}$ \\
\hline \multirow{4}{*}{ Wanita } & 2015 & 59 & 51 & 55 & 8 & $14,5 \%$ \\
\hline & 2016 & 57 & 50 & 53,5 & 7 & $13 \%$ \\
\hline & 2017 & 61 & 52 & 56,5 & 9 & $15,9 \%$ \\
\hline & 2015 & 68 & 64 & 66 & 4 & $6 \%$ \\
\hline \multirow[t]{2}{*}{ Pria } & 2016 & 73 & 67 & 70 & 6 & $8,5 \%$ \\
\hline & 2017 & 75 & 70 & 72,5 & 5 & $6,8 \%$ \\
\hline
\end{tabular}

Sumber: Human Resource Development Kutabex Beach Front Hotel, 2018

Hasil penelitian terdahulu mengenai pengaruh kepuasan kerja terhadap workfamily conflict dan turnover intention yang menunjukkan adanya research gap 
antara penelitian yang satu dengan yang lainnya. Penelitian sebelumnya dilakukan pada 335 responden dari empat Universitas Sektor Publik di Islamabad yang menemukan hasil bahwa terdapat hubungan positif dan signifikan antara workfamily conflict dan turnover intention (M. R. Khan et al., 2014). Erkmen dan Esen (2014) juga menunjukkan bahwa work-family conflict berpengaruh positif terhadap turnover intention dengan tanggung jawab terhadap keluarga sebagai prediktor utama turnover intention. Terdapat hasil yang berbeda dalam penelitian yang dilakukan oleh Lathifah dan Rohman (2014) pada Auditor Kantor Akuntan Publik di Indonesia bahwa work-family conflict tidak berpengaruh terhadap turnover intention.

Waspodo et al. (2013) melakukan penelitian pada PT. Unitex di Bogor yang menemukan bahwa kepuasan kerja memiliki pengaruh negatif dan signifikan terhadap turnover intention karyawan. Leisanyane dan Khaola (2013) menemukan bahwa kolerasi negatif dan signifikan antara kepuasan kerja dan turnover intention. Ningsih dan Arsanti (2014) membuktikan bahwa terdapat pengaruh positif kepuasan kerja terhadap turnover intention.

Yuliana dan Yuniasanti (2013) menemukan bahwa terdapat hubungan negatif antara work-family conflict dengan kepuasan kerja pada polisi wanita di POLRES Kulon Progo. Penelitian oleh Anafarta (2011) melakukan riset yang bertujuan untuk mengetahui hubungan antara work-family conflict dan kepuasan kerja yang menghasilkan adanya hubungan yang rendah atau berbanding terbalik antara workfamily conflict dan kepuasan kerja, tetapi terdapat hasil yang berbeda dari penelitian Susanto (2010) bahwa work-family conflict yang meliputi job-spouse conflict, jobparent conflict dan job-homemaker conflict tidak mempunyai pengaruh negatif dan signifikan terhadap kepuasan kerja pengusaha wanita anggota IWAPI Cabang Kota Semarang.

Salah satu teori yang digunakan dalam penelitian ini adalah traditional turnover theory. Holtom et al. (2006) menyatakan bahwa teori traditional turnover mendefinisikan bagaimana seorang karyawan merasa kurang puas dengan posisi dalam pekerjaannya, lalu memilih untuk mencari pekerjaan baru, membandingkan posisi pekerjaan mereka saat ini dengan pekerjaan pilihannya, kemudian pergi jika mereka merasa itu merupakan alternatif yang lebih baik daripada situasi saat ini yang mereka rasakan. Dari pendapat para ahli dapat dinyatakan bahwa teori traditional turnover ini menonjolkan sikap negatif dari para karyawan yang merasa tidak puas dengan pekerjaan maupun organisasinya saat ini yang menyebabkan kinerja dari karyawan tersebut menurun sehingga membuat karyawan tersebut memiliki keinginan untuk mencari pekerjaan di perusahaan lain.

Traditional turnover theory digunakan dalam penelitian ini karena di dalam teori ini menjelaskan bagaimana seorang karyawan merasa kurang puas dalam pekerjaan yang memungkinkan karyawan ini memiliki masalah atau konflik dalam perusahaan. Traditional turnover theory ini berhubungan kuat dengan kepuasan kerja karyawan dalam perusahaan. Hal tersebut dikarenakan, bila karyawan merasa puas dengan pekerjaannya seperti pekerjaan yang sesuai dengan keahlian karyawan, gaji yang sesuai dengan beban kerja, hubungan antara karyawan dengan atasan baik, dan tidak ada konflik antara pekerjaan dengan keluarga maka karyawan tersebut tidak akan memiliki keinginan untuk berpindah (turnover intention). 
Perputaran karyawan merupakan suatu istilah dalam menentukan jumlah karyawan masuk ataupun karyawan yang keluar dari perusahaan (Ardana et al., 2014: p. 53). Fenomena perputaran karyawan menjadi masalah serius yang harus dihadapi oleh perusahaan dan industri perhotelan yang disebabkan oleh minat keluar (turnover intention) karyawan yang tinggi. Tariana dan Wibawa, 2016) menyatakan bahwa minat keluar yang didefinisikan sebagai perilaku karyawan secara sukarela memiliki keinginan untuk keluar dari perusahaan (voluntary), misalnya resign atau berhenti bekerja untuk mendapatkan pekerjaan baru diperusahaan lain. Campbell et al. (2014) mengemukakan turnover Intention adalah proses kognitif berpikir tentang berhenti dari suatu pekerjaan, berencana untuk meninggalkan, atau merasakan keinginan untuk meninggalkan.

Putra dan Suana (2016) menyatakan bahwa turnover intention merupakan keinginan seseorang untuk keluar dari pekerjaannya yang berhubungan dengan ketidakpuasan yang menimbulkan keinginan untuk meninggalkan pekerjaannya untuk mencari pekerjaan lain. Waspodo et al. (2013) turnover intention merupakan keinginan karyawan untuk meninggalkan perusahaan dan mencoba untuk mencari pekerjaan lain yang lebih baik dari sebelumnya. Turnover yang tinggi berbahaya bagi perusahaan dan hal tersebut juga mengurangi efisiensi dan produktivitas organisasi (Azeez et al., 2016). Efek negatif tingginya tingkat turnover karyawan juga dapat menimbulkan pemborosan biaya yang cukup besar karena, perusahaan harus menginvestasikan biaya untuk melakukan rekrutmen, orientasi, pelatihan, lembur, dan pengawasan (Saeed et al., 2014).

Kepuasan kerja adalah sebuah tanggapan afektif atau emosional terhadap berbagai segi pekerjaan seseorang (Robert \& Kinicki, 2014: p. 169). Wibowo (2012: p. 501) mendefinisikan kepuasan kerja adalah sikap umum terhadap pekerjaan seseorang, yang menunjukkan perbedaan antara jumlah penghargaan yang diterima pekerja dan jumlah yang mereka yakini seharusnya mereka terima. Swaminathan dan Jawahar (2013) menyatakan bahwa peningkatan kepuasan kerja akan mempengaruhi kualitas kerja karyawan, dimana akan memiliki pengaruh baik terhadap pencapaian tujuan perusahaan. Rizwan (2014) meningkatkan kepuasan karyawan merupakan kunci kesuksesan organisasi, hal tersebut merupakan dasar bagi perusahaan untuk melihat seperti apa keinginan karyawan dan lingkungan kerja yang diinginkan.

Handoko (2014: p. 193) menyatakan kepuasan kerja adalah keadaan emosional yang menyenangkan atau tidak menyenangkan para karyawan memandang pekerjaan mereka. Kepuasan kerja dapat berupa sikap emosional yang positif yang ditunjukkan karyawan terhadap pekerjaannya jika dibandingkan dengan balas jasa yang mereka terima sesuai dengan apa yang diharapkannya (Aswin \& Rahyuda, 2017). Sakiru et al. (2013) menyatakan bahwa kepuasan kerja adalah hal penting bagi karyawan untuk pengembangan organisasi, karyawan berharap mendapat lebih banyak kepuasan kerja dibandingkan dengan pekerjaan mereka sebelumnya.

Kepuasan kerja mewakili perasaan negatif dan positif dari persepsi karyawan terhadap pekerjaan yang dihadapi, yaitu suatu perasaan untuk berprestasi dan meraih kesuksesan didalam pekerjaan, kepuasan kerja yang tinggi mengimplikasikan bahwa karyawan merasa senang dan nyaman dengan kondisi 
lingkungan organisasi serta mendapat penghargaan dari jerih payah hasil kerjanya (Bakotić \& Fiskovića, 2013).

Work-family conflict telah melanda populasi global karena tuntutan pekerjaan yang meningkat dan ketidakmampuan individu untuk mengelola tuntutan tersebut dengan tanggung jawab pribadi di rumah, yang akhirnya mengarah pada peningkatan tingkat stres dan konflik (Fiksenbaum, 2014). Work-family conflict merupakan suatu pengalaman yang sifatnya tidak hanya satu arah (Lee et al., 2013). Robbins dan Judge (2015) mendefinisikan work-family conflict sebagai pertentangan yang terjadi akibat adanya dua kepentingan yang tidak sejalan didalam lingkungan rumah tangga dan organisasi. Work-family conflict merupakan konflik yang timbul pada lingkungan pekerjaan terhadap hubungan keluarga, ketika individu lebih memilih bekerja maka dia akan berpotensi mengalami kendala dalam memenuhi kewajiban dan kebutuhan keluarganya (Bakker et al., 2013).

Work-family conflict dikatakan sebagai sebuah konflik peran ganda yang menuntut waktu, energi dan perhatian seseorang untuk pekerjaannya yang nantinya menimbulkan ketegangan dan mengganggu tugas serta tanggung jawab terhadap keluarga (Aslam et al., 2011). Penelitian yang dilakukan oleh Lee et al. (2013) menunjukkan bahwa work-family conflict bersumber pada hal-hal atau sesuatu yang dapat terjadi dalam lingkungan pekerjaan (work-related outcomes), seperti kepuasan kerja, komitmen organisasi dan performa kerja. Work-family conflict mungkin dapat menyebabkan sejumlah konsekuensi yang berkaitan dengan pekerjaan yang merugikan seperti berkurangnya kepuasan kerja, ketidakhadiran, kurangnya komitmen, peningkatan keinginan untuk berpindah dan pemecatan pekerjaan, serta hasil yang terkait dengan stres seperti depresi, kelelahan, kecemasan dan ketegangan (Fiksenbaum, 2014).

Penelitian yang dilakukan oleh Gao et al. (2012) dikatakan bahwa campur tangan pekerjaan pada keluarga serta campur tangan keluarga pada pekerjaan mempunyai hubungan negatif pada kepuasan kerja dan kecerdasan emosional itu melemahkan dampak work-family conflict terhadap kepuasan kerja. Rathi dan Barath (2013) berpendapat bahwa work-family conflict berpengaruh negatif terhadap kepuasan kerja. Yuliana dan Yuniasanti (2013) menemukan bahwa terdapat hubungan negatif antara work-family conflict dengan kepuasan kerja pada polisi wanita di POLRES Kulon Progo.

Penelitian oleh Paramita dan Subudi (2017) menunjukkan hasil bahwa konflik pekerjaan-keluarga berpengaruh negatif terhadap kepuasan kerja. Rantika dan Sunjoyo (2011) menemukan bahwa work-family conflict mengakibatkan rendahnya kepuasan kerja, meningkatnya absensi, menurunkan motivasi karyawan dan dalam jangka waktu tertentu dapat mengakibatkan turnover karyawan yang meningkat. Work-family conflict berpengaruh negatif terhadap kepuasan kerja (Lathifah \& Rohman, 2014).

Berdasarkan penelitian sebelumnya maka dapat dikemukakan hipotesis sebagai berikut:

$\mathrm{H} \square$ : Work-Family conflict berpengaruh negatif dan signifikan terhadap kepuasan kerja.

Penelitian sebelumnya dilakukan pada 335 responden dari empat Universitas Sektor Publik di Islamabad yang menemukan hasil bahwa terdapat hubungan 
positif dan signifikan antara work-family conflict dan turnover intention (M. R. Khan et al., 2014). Lathifah dan Rohman (2014) mengemukakan bahwa workfamily conflict berpengaruh positif terhadap turnover intention. Wulandari dan Dewi (2016) dalam penelitiannya mengatakan bahwa konflik pekerjaan- keluarga berpengaruh positif terhadap turnover intention. Konflik pekerjaan- keluarga berpengaruh positif dan signifikan terhadap turnover intention (Nanda \& Utama, 2015).

Penelitian lain oleh Nohe dan Sonntag (2014) menguji apakah ada hubungan timbal balik antara work-family conflict dan turnover intention yang menemukan bahwa turnover intention dapat meningkat apabila mendapat pengaruh dari workfamily conflict dalam lima bulan kedepan. Yunita dan Kismonto (2014) menyatakan bahwa konflik pekerjaan-keluarga memiliki hubungan positif terhadap turnover intention karyawan. Hal ini diperkuat dengan adanya penelitian sebelumnya oleh Blomme, Rheede dan Tromp (2010) dalam penelitiannya menemukan hasil bahwa sebagian besar karyawan yang berpendidikan tinggi tentang niat untuk meninggalkan organisasi menemukan bahwa work-family conflict memiliki pengaruh positif terhadap turnover intention.

Berdasarkan penelitian sebelumnya maka dapat dikemukakan hipotesis sebagai berikut:

$\mathrm{H}_{2}$ : Work-family conflict berpengaruh positif dan signifikan terhadap turnover intention.

Kepuasan kerja berpengaruh terhadap keputusan karyawan untuk tinggal atau meninggalkan organisasi, jika karyawan tidak puas dengan pekerjaan mereka, karyawan cenderung akan meninggalkan organisasi, sebaliknya jika karyawan percaya bahwa mereka diperlakukan secara adil dan mendapatkan penghargaan, mereka tidak mungkin meninggalkan organisasi (Aydogdu \& Asikgil, 2011). Kabungaidze, Mahlatshana dan Ngirande (2013) menyatakan bahwa karyawan yang tidak puas dengan pekerjaan mereka akan mengalami sikap negatif terhadap pekerjaan mereka dan sikap positif terhadap turnover intention, jadi semakin tinggi tingkat kepuasan kerja karyawan maka semakin rendah tingkat turnover intention karyawan. Kristanto et al. (2014) menyatakan bahwa kepuasan kerja berdampak negatif dan signifikan terhadap komitmen dan intensitas keluar. Waspodo et al. (2013) melakukan penelitian pada PT. Unitex di Bogor yang menemukan bahwa kepuasan kerja memiliki pengaruh negatif dan signifikan terhadap turnover intention karyawan. Leisanyane dan Khaola (2013) menemukan bahwa kolerasi negatif dan signifikan antara kepuasan kerja dan turnover intention. Candra dan Riana (2017) menunjukkan bahwa kepuasan kerja secara negatif berpengaruh signifikan terhadap turnover intention karyawan Hotel Blue Point di Desa Pecatu.

Berdasarkan penelitian sebelumnya maka dapat dikemukakan hipotesis sebagai berikut:

$\mathrm{H}_{3}$ : Kepuasan kerja berpengaruh negatif dan signifikan terhadap turnover intention.

Pengaruh konflik peran terhadap keinginan keluar kerja karyawan menunjukkan kesimpulan mediasi yang bersifat berlawanan. Ini artinya bahwa peningkatan konflik peran yang dihadapi oleh karyawan ketika bekerja akan berdampak terhadap penurunan kepuasan kerja. Irzani dan Witjaksono (2014) memperoleh hasil bahwa analisis pengaruh langsung kepuasan kerja memediasi 
secara parsial negatif dengan keinginan keluar karyawan dan memperoleh hasil bahwa kepuasan kerja memediasi secara parsial dan positif pada pengaruh konflik pekerjaan-keluarga terhadap keinginan keluar karyawan. Tariana dan Wibawa (2016) membuktikan bahwa kepuasan kerja memediasi work family conflict terhadap turnover intention karyawan wanita di PT. Bank Rakyat Indonesia (Persero) Tbk. Cabang Denpasar.

Hasil penelitian menunjukkan bahwa peran work-family conflict berpengaruh negatif parsial terhadap turnover intention melalui mediasi kepuasan kerja karyawan Hotel Grand Inna Kuta Wulandari dan Dewi (2016). Sakawangi dan Supartha (2017) memperoleh hasil konflik pekerjaan-keluarga berpengaruh positif parsial terhadap turnover intention melalui mediasi kepuasan kerja karyawan pada karyawan wanita Hotel Sun Island. Paramita dan Subudi (2017) menunjukkan bahwa peran mediasi kepuasan kerja pada pengaruh konflik pekerjaan-keluarga terhadap turnover intention yaitu positif dan signifikan.

Berdasarkan penelitian sebelumnya maka dapat dikemukakan hipotesis sebagai berikut:

$\mathrm{H}_{4}$ : Kepuasan kerja memediasi pengaruh work-family conflict terhadap turnover intention.

\section{METODE PENELITIAN}

Lokasi penelitian ini adalah Kutabex Beach Front Hotel yang berlokasi di jalan Pantai Kuta, Banjar Pande Mas, Kuta. Obyek penelitian ini adalah WorkFamily Conflict, Turnover Intention dan Kepuasan Kerja.Populasi dalam penelitian ini adalah karyawan wanita yang bekerja di Kutabex Beach Front Hotel yang berjumlah 61 orang. Penelitian ini menggunakan teknik pengumpulan sampel dengan metode purposive sampling yaitu sampel ditentukan dengan kriteria tertentu.

Penelitian ini menggunakan PLS, karena PLS merupakan teknik statistika multivarian yang melakukan perbandingan antara variabel endogen berganda dan variabel eksogen berganda, didesain untuk menyelesaikan regresi berganda ketika terjadi permasalahan spesifik pada data yaitu ketika data tidak berdistribusi normal. Tujuan PLS adalah memprediksi pengaruh variabel $\mathrm{X}$ terhadap variabel $\mathrm{Y}$ dan menjelaskan hubungan teoritis diantara kedua variabel.

\section{HASIL DAN PEMBAHASAN}

Berdasarkan usia, responden dengan rentang usia 20-30 tahun dengan persentase sebesar 58,94 \%, kemudian diikuti dengan responden berusia 31-40 tahun dengan persentase sebesar $28,56 \%$, selanjutnya responden dengan usia 4150 tahun dengan persentase sebesar 12,5\%. Hal ini menunjukkan bahwa karyawan wanita Kutabex didominasi oleh karyawan dengan rentang usia 20-30 tahun.

Berdasarkan status, responden dengan status belum menikah dengan persentase sebesar $44,6 \%$, dan responden dengan status sudah menikah dengan persentase sebesar 55,4 \%. Hal ini menunjukkan bahwa karyawan wanita Kutabex didominasi oleh karyawan dengan status sudah menikah. Berdasarkan masa kerja, responden dengan masa kerja $\leq 2,8$ tahun dengan persentase sebesar 21,44\%, selanjutnya responden dengan masa kerja $\geq 2,8$ tahun dengan persentase sebesar 
$78,56 \%$. Hal ini menunjukkan bahwa karyawan wanita Kutabex didominasi oleh karyawan dengan masa kerja $\geq 2,8$ tahun.

Berdasarkan pendidikan terakhir, responden dengan pendidikan SMA dengan persentase sebesar $12,5 \%$, selanjutnya responden dengan pendidikan Diploma dengan persentase sebesar 35,71\%. Responden dengan pendidikan S1 dengan persentase 48,21\% dan responden dengan pendidikan S2 dengan persentase sebesar $3,57 \%$. Hal ini menunjukkan bahwa karyawan wanita Kutabex didominasi oleh karyawan dengan pendidikan terakhir S1.

Instrumen yang valid dapat digunakan untuk mengukur apa yang seharusnya diukur. Seluruh koefisien korelasi dari indikator variabel yang diuji nilainya lebih besar dari 0,30 (r > 0,3). Hal tersebut menunjukkan bahwa seluruh indikator yang terdapat pada penelitian ini terbukti valid, sebagaimana disajikan dalam Tabel 2.

Tabel 2.

Hasil uji validitas

\begin{tabular}{ccccc}
\hline No & Variabel & Item Pernyataan & $\begin{array}{c}\text { Korelasi Item } \\
\text { Pernyataan }\end{array}$ & Keterangan \\
\hline 1 & Work-Family Conflict & $\mathrm{X} .1$ & 0,907 & Valid \\
& $(\mathrm{X})$ & $\mathrm{X} .2$ & 0,840 & Valid \\
& $\mathrm{X} .3$ & 0,673 & Valid \\
\hline 2 & Kepuasan Kerja & $\mathrm{M} .1$ & 0,793 & Valid \\
& (M) & $\mathrm{M} .2$ & 0,863 & Valid \\
& & $\mathrm{M} .3$ & 0,835 & Valid \\
& & $\mathrm{M} .4$ & 0,709 & Valid \\
& Turnover intention & Y.1 & 0,809 & Valid \\
\hline 3 & (Y) & Y.2 & 0,917 & Valid \\
& & Y.3 & 0,842 & Valid \\
& & & 0,848 & Valid \\
\hline
\end{tabular}

Sumber: Data diolah, 2018

Tabel 2. menunjukkan bahwa instrumen-instrumen pada setiap variabel dalam penelitian ini memiliki skor total diatas 0,3 . Hasil uji validitas dari 3 variabel yang diteliti menghasilkan korelasi yang terkecil adalah 0,673 dan korelasi yang terbesar adalah 0,917 . Hasil uji validitas yang dilakukan dengan kuesioner dalam penelitian ini adalah valid sehingga digunakan dalam penelitian ini.

Uji reliabilitas digunakan untuk mengukur konsistensi suatu variabel pada penelitian. Apabila suatu alat pengukur dipakai dua kali untuk mengukur gejala yang sama dan hasil pengukuran yang diperoleh relatif konsisten, maka alat pengukuran tersebut reliabel. Instrumen dikatakan reliabel untuk mengukur variabel apabila memiliki nilai Cronbach Alpha $>0,60$.

Tabel 3. menunjukkan masing-masing nilai Cronbach's Alpha pada tiap instrumen tersebut lebih besar dari 0,60 (Cronbach Alpha>0,6). Hal tersebut menunjukkan bahwa semua instrumen reliabel sehingga dapat digunakan untuk melakukan penelitian.

Model pengukuran outer model dengan indikator reflektif dievaluasi dengan convergent dan discriminate validity dari indikatornya serta composite reliability untuk keseluruhan indikatornya. 
Tabel 3.

Hasil uji reliabilitas

\begin{tabular}{clcc}
\hline No & \multicolumn{1}{c}{ Variabel } & Cronbach Alpha & Keterangan \\
\hline 1 & Work-Family Conflict $(\mathrm{X})$ & 0,739 & Reliabel \\
2 & Kepuasan Kerja (M) & 0,858 & Reliabel \\
3 & Turnover Intention $(\mathrm{Y})$ & 0,829 & Reliabel \\
\hline
\end{tabular}

Sumber: Data diolah, 2018

Tabel 4.

Hasil uji validitas discriminant cross loading

\begin{tabular}{cccc}
\hline & Kepuasan Kerja $(\mathbf{M})$ & Turnover Intention $(\mathbf{Y})$ & Work-family Conflict $(\mathbf{X})$ \\
\hline M.1 & $\mathbf{0 , 8 3 1}$ & $-0,603$ & $-0,494$ \\
M.2 & $\mathbf{0 , 8 8 0}$ & $-0,583$ & $-0,460$ \\
M.3 & $\mathbf{0 , 7 4 4}$ & $-0,595$ & $-0,392$ \\
M.4 & $\mathbf{0 , 7 9 3}$ & $-0,561$ & $-0,538$ \\
M.5 & $\mathbf{0 , 7 9 3}$ & $-0,626$ & $-0,414$ \\
X.1 & $-0,440$ & 0,488 & $\mathbf{0 , 9 3 0}$ \\
X.2 & $-0,617$ & 0,624 & $\mathbf{0 , 8 9 4}$ \\
X.3 & $-0,363$ & 0,355 & $\mathbf{0 , 7 5 7}$ \\
Y.1 & $-0,580$ & $\mathbf{0 , 9 0 5}$ & 0,505 \\
Y.2 & $-0,577$ & $\mathbf{0 , 8 6 6}$ & 0,582 \\
Y.3 & $-0,756$ & $\mathbf{0 , 8 6 8}$ & 0,473 \\
\hline \multicolumn{2}{l}{ Sumber: Data diolah, 2018} & &
\end{tabular}

Berdasarkan Tabel 4. diperlihatkan bahwa semua nilai cross loading setiap indikator pada masing - masing variabel lebih besar dari 0,5 Dengan demikian dapat dinyatakan bahwa data dalam penelitian valid.

Tabel 5.

Hasil uji validitas convergent AVE

\begin{tabular}{lc}
\hline & Average Variance Extracted (AVE) \\
\hline Kepuasan Kerja & 0,656 \\
Turnover Intention & 0,774 \\
Work-family Conflict & 0,745 \\
\hline
\end{tabular}

Sumber: Data diolah, 2018

Berdasarkan Tabel 5. diperlihatkan bahwa semua nilai AVE validitas confergent lebih besar dari 0,5 . Dengan demikian dapat dinyatakan bahwa data dalam penelitian valid.

Berdasarkan Tabel 6. diperlihatkan bahwa semua nilai Cronbach's alpha pada masing - masing variabel lebih besar dari 0,70. Dengan demikian dapat dinyatakan bahwa data dalam penelitian reliabel.

Berdasarkan Tabel 7. diperlihatkan bahwa semua nilai Composite reliability pada masing - masing variabel lebih besar dari 0,70. Dengan demikian dapat dinyatakan bahwa data dalam penelitian reliabel.

Berdasarkan Tabel 7. diperlihatkan bahwa semua nilai Composite reliability pada masing - masing variabel lebih besar dari 0,70. Dengan demikian dapat dinyatakan bahwa data dalam penelitian reliabel. 
Tabel 6.

Hasil uji reliabilitas cronbach's alpha

\begin{tabular}{lc}
\hline & Cronbach's Alpha \\
\hline Kepuasan Kerja & 0,867 \\
Turnover Intention & 0,854 \\
Work-family Conflict & 0,832 \\
\hline
\end{tabular}

Sumber: Data diolah, 2018

Tabel 7.

Hasil uji reliabilitas composite realibility

\begin{tabular}{lc}
\hline & Composite Reliability \\
\hline Kepuasan Kerja & 0,905 \\
Turnover Intention & 0,911 \\
Work-family Conflict & 0,897 \\
\hline Sumber: Data diolah, 2018
\end{tabular}

Sumber: Data diolah, 2018

Tabel 8.

Hasil uji validitas convergent loading factor

\begin{tabular}{cccc}
\hline & Kepuasan Kerja (M) & Turnover Intention (Y) & Work-family Conflict (X) \\
\hline M.1 & $\mathbf{0 , 8 3 1}$ & & \\
M.2 & $\mathbf{0 , 8 8 0}$ & & \\
M.3 & $\mathbf{0 , 7 4 4}$ & & \\
M.4 & $\mathbf{0 , 7 9 3}$ & & \\
M.5 & $\mathbf{0 , 7 9 3}$ & & $\mathbf{0 , 9 3 0}$ \\
X.1 & & & $\mathbf{0 , 8 9 4}$ \\
X.2 & & & $\mathbf{0 , 7 5 7}$ \\
X.3 & & $\mathbf{0 , 9 0 5}$ & \\
Y.1 & & $\mathbf{0 , 8 6 6}$ & \\
Y.2 & & $\mathbf{0 , 8 6 8}$ & \\
Y.3 & &
\end{tabular}

Sumber: Data diolah, 2018

Berdasarkan Tabel 8 diperlihatkan bahwa semua nilai loading factor pada uji validitas confergent lebih besar dari 0,70 . Dengan demikian dapat dinyatakan bahwa data dalam penelitian valid.

Berdasarkan Tabel 9. diperoleh nilai R-square untuk variabel Kepuasan Kerja sebesar 0,325 yang menunjukkan pengaruh yang cukup kuat. Nilai R-square untuk variabel Turnover Intention sebesar 0,582 yang menunjukkan pengaruh yang kuat.

Hasil dari predictive-relevance $\left(\mathrm{R}^{2}\right)$ yaitu 0,5914 , ini berarti hasil perhitungan memperlihatkan R-square lebih dari 0 (nol), maka model layak dikatakan memiliki nilai prediktif yang relevan.

Pengujian hipotesis dilakukan dengan perbandingan nilai t-value dengan $\mathrm{t}$ statistics dan p-value dengan tingkat signifikan 5\%. Jika t-statistics lebih tinggi dibandingkan nilai t-value, berarti hipotesis terdukung atau diterima. 
Hasil evaluasi model pengukuran (inner model) adalah sebagai berikut:

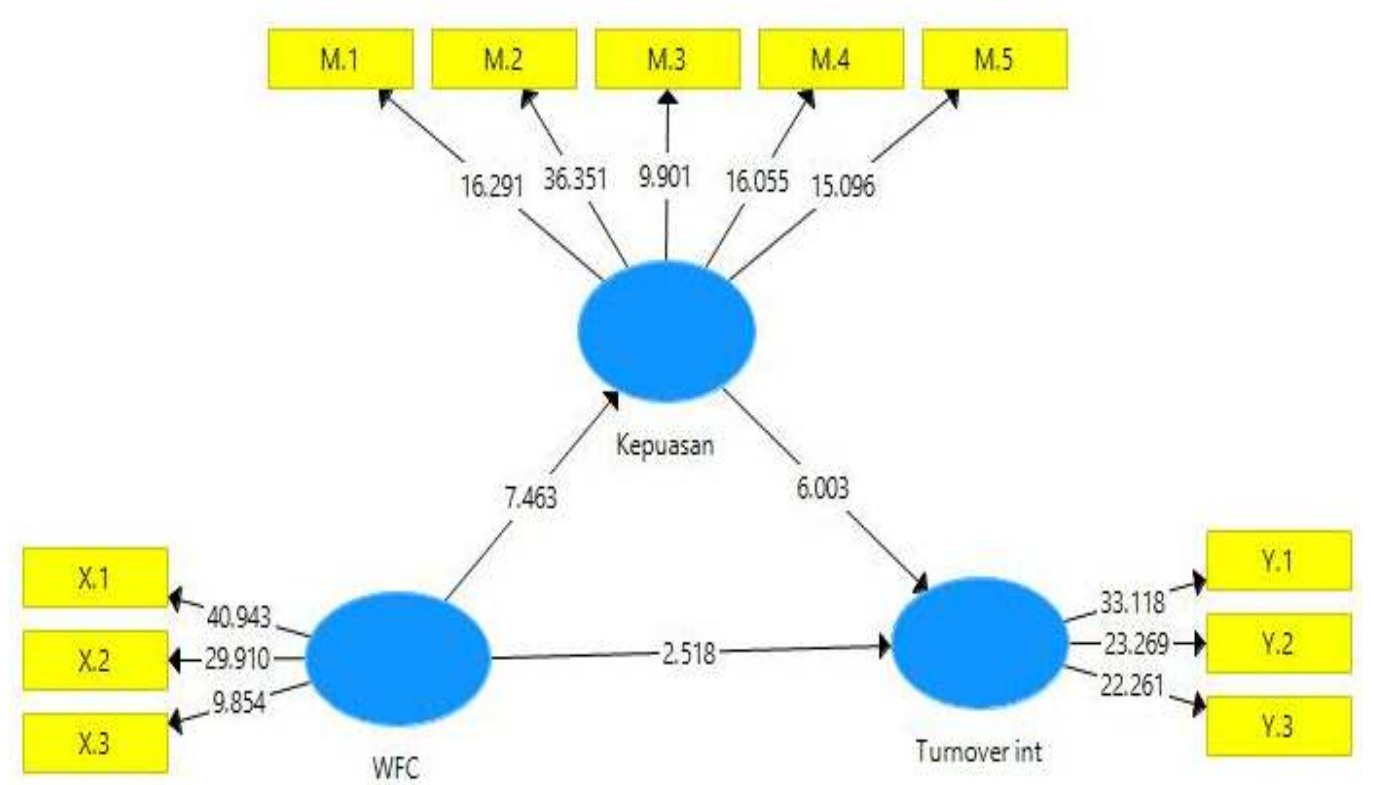

Gambar 1. Inner Model

Sumber: Data diolah, 2018

Tabel 9.

Hasil uji R-square

\begin{tabular}{lcc}
\hline & R Square & R-Square Adjusted \\
\hline Kepuasan Kerja & 0,325 & 0,312 \\
Turnover Intention & 0,582 & 0,566 \\
\hline Simber: Datr
\end{tabular}

Simber: Data diolah, 2018

$$
\begin{aligned}
\mathrm{R}^{2} & \left.=1\left(1-\mathrm{R}_{1}\right)^{2} \cdot\left(1-\mathrm{R}_{2}\right)^{2}\right) \ldots \ldots \ldots \ldots \ldots \\
& =1\left(1-(0,325)^{2}\right) \cdot\left(1-(0,582)^{2}\right) \\
& =1(1-0,1056) \cdot(1-0,3387) \\
& =1(0,8944) \cdot(0,6613) \\
& =1.0,5914 \\
& =0,5914
\end{aligned}
$$

Berdasarkan Tabel 10. Nilai p-value variabel work-family conflict terhadap kepuasan kerja sebesar 0,000 dibandingkan dengan signifikan sebesar 0,05. Karena nilai p-value $<$ signifikan $(0,000<0,05)$ dengan nilai beta sebesar $-0,570$ dan nilai t-statistics sebesar 7,463 yang dibandingkan dengan t-tabel dengan signifikan 0,05 dan derajat kebebasan $\mathrm{n}-\mathrm{k}=56-3=53$ sebesar 2,006. Karena nilai t-statistics > t-value $(7,463>2,006)$ maka dapat disimpulkan bahwa work-family conflict berpengaruh negatif dan signifikan terhadap kepuasan kerja.

Nilai p-value variabel work-family conflict terhadap turnover intention sebesar 0,012 dibandingkan dengan signifikan sebesar 0,05. Karena nilai p-value $<$ signifikan $(0,012<0,05)$ dengan nilai beta sebesar positif 0,253 dan nilai t-statistics 
sebesar 2,518 yang dibandingkan dengan t-tabel dengan signifikan 0,05 dan derajat kebebasan $\mathrm{N}-\mathrm{k}=56-3=53$ sebesar 2,006. Karena nilai $\mathrm{t}$-statistics $>\mathrm{t}$-value $(2,518>2,006)$ maka dapat disimpulkan bahwa work-family conflict berpengaruh positif dan signifikan terhadap turnover intention.

Tabel 10.

Hasil uji hubungan kausalitas

\begin{tabular}{|c|c|c|c|c|c|}
\hline & $\begin{array}{l}\text { Original } \\
\text { Sample } \\
\text { (O) }\end{array}$ & $\begin{array}{l}\text { Sample } \\
\text { Mean } \\
\text { (M) }\end{array}$ & $\begin{array}{l}\text { Standard } \\
\text { Deviation } \\
\text { (STDEV) }\end{array}$ & $\begin{array}{l}\text { T Statistics } \\
(|\mathrm{O} / \mathrm{STDEV}|)\end{array}$ & $\begin{array}{c}P \\
\text { Values }\end{array}$ \\
\hline $\begin{array}{l}\text { Work-family Conflict -> } \\
\text { Kepuasan Kerja }\end{array}$ & $-0,570$ & $-0,580$ & 0,076 & 7.463 & 0,000 \\
\hline $\begin{array}{l}\text { Work-family Conflict- } \\
>\text { Turnover Intention }\end{array}$ & 0,253 & 0,249 & 0,101 & 2.518 & 0,012 \\
\hline $\begin{array}{l}\text { Kepuasan Kerja } \\
\text { Turnover Intention }\end{array}$ & $-0,589$ & $-0,590$ & 0,098 & 6.003 & 0,000 \\
\hline $\begin{array}{l}\text { Work-Family Conflict - } \\
\text { > Kepuasan Kerja -> } \\
\text { Turnover Intention }\end{array}$ & 0,336 & 0,343 & 0,079 & 4.264 & 0,000 \\
\hline
\end{tabular}

Sumber: Data diolah, 2018

Nilai p-value variabel kepuasan kerja terhadap turnover intention sebesar 0,000 dibandingkan dengan signifikan sebesar 0,05 . Karena nilai p-value < signifikan $(0,000<0,05)$ dengan nilai beta sebesar $-0,589$ dan nilai t-statistics sebesar 6,003 yang dibandingkan dengan t-tabel dengan signifikan 0,05 dan derajat kebebasan $\mathrm{N}-\mathrm{k}=56-3=53$ sebesar 2,006. Karena nilai t-statistics $>\mathrm{t}$-value $(6,003>2,006)$ maka dapat disimpulkan bahwa kepuasan kerja berpengaruh negatif dan signifikan terhadap turnover intention.

Nilai p-value variabel work-family conflict dengan kepuasan kerja terhadap turnover intention sebesar 0,000 dibandingkan dengan signifikan sebesar 0,05. Karena nilai p-value $<$ signifikan $(0,000<0,05)$ dengan nilai beta sebesar positif 0,336 dan nilai t-statistics sebesar 4,264 yang dibandingkan dengan t-tabel dengan signifikan 0,05 dan derajat kebebasan $\mathrm{N}-\mathrm{k}=56-3=53$ sebesar 2,006. Karena nilai t-statistics $>$ t-value $(4,264>2,006)$ maka dapat disimpulkan bahwa kepuasan kerja memediasi pengaruh work-family conflict terhadap turnover intention.

VAF dihitung dengan perhitungan sebagai berikut:

$$
\begin{aligned}
\mathrm{VAF} & =\frac{\beta_{1} \cdot \beta_{2}}{\beta_{1} \cdot \beta_{2}+\beta_{3}} \ldots \ldots \ldots \ldots \ldots \\
& =\frac{-0,570 \cdot 0,253}{-0,570.0,253+-0,589} \\
& =\frac{-0,144}{-0,144+-0,589} \\
& =\frac{-0,144}{-0,733}=0,20 \\
& =0,20 \times 100 \% \\
& =20 \%
\end{aligned}
$$


Berdasarkan hasil perhitungan nilai VAF yaitu 20\% maka dapat disimpulkan peran mediasi kepuasan kerja pada pengaruh work-family conflict terhadap turnover intention adalah mediasi parsial.

Pengujian hipotesis pada pengaruh work-family conflict terhadap kepuasan kerja menunjukkan bahwa work-family conflict berpengaruh negatif dan signifikan terhadap kepuasan kerja. Hasil pengujian tersebut mendukung hipotesis pertama yaitu work-family conflict berpengaruh negatif dan signifikan terhadap kepuasan kerja. Hal ini menjelaskan bahwa semakin tinggi work-family conflict terhadap pekerjaan maka kepuasan kerja semakin rendah. Pengaruh signifikan ini disumbangkan oleh adanya pernyataan "pekerjaan saya membutuhkan waktu penyelesaian yang membuat saya sulit memenuhi tanggung jawab terhadap keluarga" dan "permasalahan keluarga membuat saya kehilangan konsentrasi dalam menyelesaikan pekerjaan". Karyawan wanita yang mengalami work-family conflict yang tinggi akan menyebabkan ketidakpuasan dalam bekerja.

Hasil penelitian ini mengembangkan temuan dari Gao et al. (2012) dikatakan bahwa campur tangan pekerjaan pada keluarga serta campur tangan keluarga pada pekerjaan mempunyai hubungan negatif pada kepuasan kerja dan kecerdasan emosional itu melemahkan dampak work-family conflict terhadap kepuasan kerja. Rathi dan Barath (2013) berpendapat bahwa work-family conflict berpengaruh negatif terhadap kepuasan kerja. Yuliana dan Yuniasanti (2013) menemukan bahwa terdapat hubungan negatif antara work-family conflict dengan kepuasan kerja pada polisi wanita di POLRES Kulon Progo. Penelitian oleh Paramita dan Subudi (2017) menunjukkan hasil bahwa konflik pekerjaan-keluarga berpengaruh negatif terhadap kepuasan kerja. Rantika dan Sunjoyo (2011) menemukan bahwa work-family conflict mengakibatkan rendahnya kepuasan kerja, meningkatnya absensi, menurunkan motivasi karyawan dan dalam jangka waktu tertentu dapat mengakibatkan turnover karyawan yang meningkat. Work-family conflict berpengaruh negatif terhadap kepuasan kerja (Lathifah \& Rohman, 2014).

Pengujian hipotesis pada pengaruh work-family conflict terhadap turnover intention menunjukkan bahwa work-family conflict berpengaruh positif dan signifikan terhadap turnover intention. Hasil pengujian tersebut mendukung hipotesis kedua yaitu work-family conflict berpengaruh positif dan signifikan terhadap turnover intention. Hal ini menjelaskan bahwa semakin tinggi work-family conflict terhadap pekerjaan maka tingkat turnover intention semakin tinggi. Pengaruh signifikan ini disumbangkan oleh adanya pernyataan "karena tugas yang berhubungan dengan pekerjaan, membuat saya harus menyiapkan perubahan rencana bagi kegiatan keluarga", dikarenakan work-family conflict yang dialami karyawan wanita tinggi akan menyebabkan tingkat turnover intention tinggi.

Hasil penelitian ini mengembangkan temuan dari M. R. Khan et al. (2014) yang menyatakan bahwa penelitian sebelumnya dilakukan pada 335 responden dari empat Universitas Sektor Publik di Islamabad yang menemukan hasil bahwa terdapat hubungan positif dan signifikan antara work-family conflict dan turnover intention. Lathifah dan Rohman (2014) mengemukakan bahwa work-family conflict berpengaruh positif terhadap turnover intention. Wulandari dan Dewi (2016) dalam penelitiannya mengatakan bahwa konflik pekerjaan-keluarga berpengaruh positif terhadap turnover intention. Konflik pekerjaan-keluarga berpengaruh positif dan 
signifikan terhadap turnover intention (Nanda \& Utama, 2015). Yunita dan Kismono (2014) menyatakan bahwa konflik pekerjaan-keluarga memiliki hubungan positif terhadap turnover intention karyawan.

Pengujian hipotesis pada pengaruh kepuasan kerja terhadap turnover intention menunjukkan bahwa kepuasan kerja berpengaruh negatif dan signifikan terhadap turnover intention. Hasil pengujian tersebut mendukung hipotesis ketiga yaitu kepuasan kerja berpengaruh negatif dan signifikan terhadap turnover intention. Hal ini menjelaskan bahwa semakin rendah tingkat kepuasan kerja karyawan terhadap pekerjaan maka tingkat turnover intention semakin tinggi. Pengaruh signifikan ini disumbangkan oleh adanya pernyataan pertama yaitu "saya menerima gaji sesuai dengan beban kerja saya", pernyataan kedua yaitu "pimpinan selalu memberikan pengarahan kepada karyawan" dan pernyataan ketiga yaitu "hubungan kerja saya dengan rekan kerja sudah berjalan dengan baik", dikarenakan tingkat kepuasan karyawan wanita rendah menyebabkan tingkat turnover intention karyawan wanita tinggi.

Hasil penelitian ini mengembangkan temuan dari Kabungaidze et al. (2013) menyatakan bahwa karyawan yang tidak puas dengan pekerjaan mereka akan mengalami sikap negatif terhadap pekerjaan mereka dan sikap positif terhadap turnover intention, jadi semakin tinggi tingkat kepuasan kerja karyawan maka semakin rendah tingkat turnover intention karyawan. Kristanto et al. (2014) menyatakan bahwa kepuasan kerja berdampak negatif dan signifikan terhadap komitmen dan intensitas keluar. Waspodo et al. (2013) melakukan penelitian pada PT. Unitex di Bogor yang menemukan bahwa kepuasan kerja memiliki pengaruh negatif dan signifikan terhadap turnover intention karyawan. Leisanyane dan Khaola (2013) menemukan bahwa kolerasi negatif dan signifikan antara kepuasan kerja dan turnover intention. Candra dan Riana (2017) menunjukkan bahwa kepuasan kerja secara negatif berpengaruh signifikan terhadap turnover intention karyawan Hotel Blue Point di Desa Pecatu.

Pengujian hipotesis pada peran kepuasan kerja memediasi pengaruh workfamily conflict terhadap turnover intention berpengaruh positif dan kepuasan kerja memediasi secara parsial. Hasil uji VAF menunjukkan hasil bahwa kepuasan kerja memediasi secara parsial dengan nilai VAF $20 \%$ pada pengaruh work-family conflict terhadap turnover intention. Hasil pengujian tersebut mendukung hipotesis keempat yaitu kepuasan kerja memediasi pengaruh work-family conflict terhadap turnover intention. Hasil penelitian ini mengembangkan temuan Irzani dan Witjaksono (2014) memperoleh hasil bahwa analisis pengaruh langsung kepuasan kerja memediasi secara parsial negatif dengan keinginan keluar karyawan dan memperoleh hasil bahwa kepuasan kerja memediasi secara parsial dan positif pada pengaruh konflik pekerjaan-keluarga terhadap keinginan keluar karyawan.

Tariana dan Wibawa (2016) membuktikan bahwa kepuasan kerja memediasi work family conflict terhadap turnover intention karyawan wanita di PT. Bank Rakyat Indonesia (Persero) Tbk. Cabang Denpasar. Sakawangi dan Supartha (2017) memperoleh hasil konflik pekerjaan-keluarga berpengaruh positif parsial terhadap turnover intention melalui mediasi kepuasan kerja karyawan pada karyawan wanita Hotel Sun Island. Paramita dan Subudi (2017) menunjukkan 
bahwa peran mediasi kepuasan kerja pada pengaruh konflik pekerjaan-keluarga terhadap turnover intention yaitu positif dan signifikan.

Implikasi dari hasil penelitian mencakup dua hal, yaitu implikasi teoritis dan praktis. Implikasi teoritis berhubungan dengan kontribusi bagi perkembangan teori tentang pengaruh langsung work-family conflict dan kepuasan kerja terhadap turnover intention serta peran peran mediasi kepuasan kerja pada pengaruh workfamily conflict terhadap turnover intention. Dengan demikian, hasil penelitian ini memberikan dukungan empiris dan dapat dinyatakan memperkuat hasil-hasil studi terdahulu.

Implikasi praktis berkaitan dengan kontribusi penelitian terhadap turnover intention karyawan wanita Kutabex Beach Front Bali. Berdasarkan hasil penelitian ini diharapkan digunakan sebagai masukan bagi Kutabex Beach Front Bali, sehingga dapat mengurangi tingkat turnover intention pada karyawan wanita. Salah satu cara agar perusahaan dapat mengurangi tingkat turnover yaitu mengadakan sebuah acara keluarga seperti family gathering untuk menurunkan tingkat workfamily conflict karyawan wanita dan meningkatkan kepuasan kerja karyawan seperti penempatan karyawan yang sesuai dengan keahliannya dan kebijakan promosi jabatan untuk karyawan wanita. Sebab work-family conflict dan kepuasan kerja dapat mempengaruhi tingkat turnover intention.

\section{SIMPULAN}

Work-family conflict berpengaruh negatif dan signifikan terhadap kepuasan kerja. Hal ini menunjukkan bahwa semakin tinggi tingkat work-family conflict maka semakin rendah kepuasan kerja yang dirasakan karyawan pada perusahaan tersebut. Work-family conflict berpengaruh positif dan signifikan terhadap turnover intention. Hal ini menunjukkan bahwa semakin tinggi tingkat work-family conflict maka semakin tinggi pula tingkat turnover intention yang dirasakan karyawan pada perusahaan tersebut. Kepuasan kerja berpengaruh negatif dan signifikan terhadap turnover intention. Hal ini menunjukkan bahwa semakin tinggi tingkat kepuasan kerja karyawan maka semakin rendah turnover intention yang dirasakan karyawan pada perusahaan tersebut. Kepuasan kerja berperan sebagai mediasi secara parsial pada pengaruh work-family conflict terhadap turnover intention.

Saran secara teoritis untuk menurunkan tingkat turnover intention pada Kutabex Beach Front Hotel ada beberapa hal yang harus diperhatikan oleh perusahaan yaitu work-family conflict dan kepuasan kerja.

Saran secara praktis untuk menurunkan tingkat turnover intention pada karyawan wanita yaitu, disarankan agar Kutabex Beach Front Hotel lebih memperhatikan indikator behavior-based conflict pada variabel work-family conflict dikarenakan memiliki nilai rata-rata tertinggi, sebaiknya pembagian beban kerja sebisa mungkin bersifat jelas dan dapat diselesaikan ketika berada di hotel, sehingga karyawan tidak perlu menyiapkan perubahan rencana untuk kegiatan keluarganya.

Kutabex Beach Front Hotel hendaknya lebih memperhatikan indikator pekerjaan itu sendiri dan promosi jabatan pada variabel kepuasan kerja dikarenakan memiliki nilai rata-rata terendah, sebaiknya pihak Kutabex Beach Front Hotel menempatkan karyawan sesuai dengan keahliannya dan mampu menjalankan 
kegiatan promosi bagi karyawannya yang dianggap pantas untuk mendapatkan promosi jabatan sehingga dapat menimbulkan kenyamanan bagi karyawan itu sendiri. Indikator pikiran untuk keluar dari organisasi dan indikator keinginan untuk mencari pekerjaan baru pada variabel turnover intention harus diperhatikan dengan cara pihak Kutabex Beach Front Hotel berlaku adil terhadap semua karyawan wanita dan mampu memenuhi keinginan karyawan. Bagi peneliti selanjutnya yang ingin melakukan penelitian terkait, diharapkan untuk mempertimbangkan komitmen organisasional yang memiliki hubungan dengan work-family conflict, kepuasan kerja dan turnover intention. Selain itu peneliti selanjutnya dapat menggunakan teknik analisis data lain seperti teknik moderasi dan melakukan penelitian pada jenis pekerjaan yang berbeda di beberapa industri lainnya seperti industri perbankan, pertanian, tekstil, manufaktur, perkebunan agar hasil penelitian dapat bervariasai yang dapat memperkaya referensi tentang work-family conflict, kepuasan kerja dan turnover intention.

\section{REFERENSI}

Afsar, B., \& Rehman, Z. U. (2017). Relationship between Work-Family Conflict, Job Embeddedness, Workplace Flexibility, and Turnover Intentions. Makara Hubs-Asia, 21(2), 92-104. https://doi.org/10.7454/mssh.v21i2.3504

Anafarta, N. (2011). The Relationship between Work-Family Conflict and Job Satisfaction: A Structural Equation Modeling ( SEM ) Approach. International Journal of Business and Management, 6(4), 168-177. https://doi.org/10.5539/ijbm.v6n4p168

Ardana, I. K., Mujiati, N. W., \& Utama, I. W. M. (2014). Manajemen Sumber Daya Manusia (1st ed.). Yogyakarta: Graha Ilmu.

Aslam, R., Shumaila, S., Azhar, M., \& Sadaqat, S. (2011). Work-Family Conflicts : Relationship between Work-Life Conflict and Employee Retention - A Comparative Study of Public and Private Sector Employees. Interdisciplinary Journal of Research in Business, 1(February), 18-29. Retrieved from http://joc.hcc.edu.pk/faculty_publications/workfamilyconflicts.pdf

Aswin, A. E., \& Rahyuda, A. G. (2017). Pengaruh Perceived Organizational Support Terhadap Organizational Citizenship Behavior Dengan Variabel Kepuasan Kerja Sebagai Mediasi. E-Jurnal Manajemen Unud, 6(5), 27292755. Retrieved from https://ojs.unud.ac.id/index.php/Manajemen/article/ view/29846/18532

Aydogdu, S., \& Asikgil, B. (2011). International Review of Management and Marketing An Empirical Study of the Relationship Among Job Satisfaction , Organizational Commitment and Turnover Intention. International Review of Management and Marketing, 1(3), 43-53. Retrieved from https://pdfs.semanticscholar.org/604e/1921d4bb13d9dcc3427d67947aaee206 3052.pdf 
Azeez, R. O., Jayeoba, F., \& Adeoye, A. O. (2016). Job Satisfaction, Turnover Intention and Organizational Commitment. Journal of Management Research, $8(2), \quad 102-114$. Retrieved from http://www.bvimsr.com/documents/ publication/2016V8N2/2.pdf

Bakker, A. B., Shimazu, A., Demerouti, E., Kawakami, N., \& Shimada, K. (2013). Work engagement versus workaholism: a test of the spillover-crossover model. Journal of Managerial Psychology, 29(1), 63-80. https://doi.org/10.1108/JMP-05-2013-0148

Bakotić, D., \& Fiskovića, C. (2013). Relationship between Working Conditions and Job Satisfaction: The Case of Croatian Shipbuilding Company. International Journal of Business and Social Science, 4(2), 206-213. Retrieved from http://www.ijbssnet.com/journals/Vol_4_No_2_February_2013/22.pdf

Blomme, R. J., Rheede, A. Van, \& Tromp, D. M. (2010). Work-Family Conflict as a Cause for Turnover Intentions in the Hospitality Industry. Sage Journal, 10(4), 269-285. https://doi.org/https://doi.org/10.1057/thr.2010.15

Burke, R. J., \& El-Kot, G. (2010). Correlates of work-family conflicts among managers in Egypt. International Journal of Islamic and Middle Eastern Finance and Management, 3(2), 113-131. https://doi.org/10.1108/ 17538391011054363

Campbell, J. W., Im, T., \& Jeong, J. (2014). Internal Efficiency and Turnover Intention: Evidence From Local Government in South Korea. Sage Journal, 43(2), 259-282. https://doi.org/https://doi.org/10.1177/0091026014524540

Candra, P. D. K., \& Riana, I. G. (2017). Peran Komitmen Organisasional Memediasi Pengaruh Kepuasan Kerja Terhadap Turnover Intention. E-Jurnal Manajemen Unud, 6(10), 5287-5318. Retrieved from https://ojs.unud.ac.id/index.php/Manajemen/article/view/31744/20953

Dewi, K. A. B., \& Wibawa, I. M. A. (2016). Pengaruh Stress Kerja Pada Turnover Intention yang Dimediasi Kepuasan Kerja Agen AJB Bumiputera 1912. EJurnal Manajemen Unud, 5(6), 3560-3588. Retrieved from https://ojs.unud.ac.id/index.php/Manajemen/article/view/18195/13994

Erkmen, T., \& Esen, E. (2014). Work Family, Family Work Conflict and Turnover intentions Among The Representatives of Insurance Agencies. Journal of Business, Economics \& Finance, 3(3), 302-312. Retrieved from http://dergipark.gov.tr/download/article-file/374551

Fiksenbaum, L. M. (2014). Supportive work-family environments: implications for work-family conflict and well-being. The International Journal of Human Resource Management, 25(5), 653-672. https://doi.org/10. 
$1080 / 09585192.2013 .796314$

Gao, Y., Shi, J., Niu, Q., \& Wang, L. (2012). Work-Family Conflict and Job Satisfaction: Emotional Intelligence as a Moderator. Stress and Health, 29(3), 1-12. https://doi.org/https://doi.org/10.1002/smi.2451

Handoko, T. H. (2014). Manajemen Sumber Daya Manusia (2nd ed.). Yogyakarta: BPFE.

Hasibuan, S. M. (2014). Manajemen Sumber Daya Manusia (Revition). Jakarta: PT Bumi Aksara.

Holtom, B. C., Mitchell, T. R., \& Lee, T. W. (2006). Increasing human and social capital by applying job embeddedness theory. Organizational Dynamics, 35(4), 316-331. https://doi.org/10.1016/j.orgdyn.2006.08.007

Hutagalung, I. D. N., \& Artha, I. M. (2018). Pengaruh Keadilan Organisasional Terhadap Komitmen Organisasional dan Turnover Intention Karyawan Pada PT. Bank Rakyat Indonesia. E-Jurnal Manajemen Unud, 7(1), 221-250. https://doi.org/https://doi.org/10.24843/EJMUNUD.2018.v7.i01.p09

Irzani, D., \& Witjaksono, A. D. (2014). Pengaruh Konflik Peran dan Ambiguitas Peran Terhadap Keinginan Keluar Karyawan dengan Kepuasan Kerja sebagai Variabel Mediasi pada PT. Asuransi Raksa Pratikarsa di Surabaya. Jurnal Ilmu Manajemen, 2(1), 266-281. Retrieved from https://drive.google.com/ open?id=0B8ZDDJq_Cxu1bUx3b3NjYUZ6Uk0

Kabungaidze, T., Mahlatshana, N., \& Ngirande, H. (2013). The Impact of Job Satisfaction and Some Demographic Variables on Employee Turnover Intentions. International Journal of Business Administration, 4(1), 53-65. https://doi.org/10.5430/ijba.v4n1p53

Khan, M. A. S., \& Du, J. (2014). An Empirical Study of Turnover Intentions in Call Centre Industry of Pakistan. Journal of Human Resource and Sustainability Studies, 2(2), 206-214. Retrieved from https://file.scirp.org/pdf/JHRSS_ 2014120511534374.pdf

Khan, M. R., Nazir, N., Kazmi, S., Khalid, A., Kiyani, Talat, M., \& Shahzad, A. (2014). Work-Family Conflict and Turnover Intentions : Mediating Effect of Stress. International Journal of Humanities and Social Science, 4(5), 92-100. Retrieved from http://www.ijhssnet.com/journals/Vol_4_No_5_1_March_ 2014/12removed.pdf

Kristanto, S., Rahyuda, I. K., \& Riana, I. G. (2014). Pengaruh Keadilan Organisasional Terhadap Kepuasan Kerja Dan Dampaknya Terhadap Komitmen, Dan Intensi Keluar di PT Indonesia Power UPB Bali. E-Jurnal 
Ekonomi Dan Bisnis Universitas Udayana, 3(6), 25-80. Retrieved from https://ojs.unud.ac.id/index.php/EEB/article/view/6447

Ksama, I. B. P. T., \& Wibawa, I. M. A. (2016). Pengaruh Leader-MemberExchange, Role Stress dan Perceived Organizational Support Terhadap Turnover Intention. E-Jurnal Manajemen Unud, 5(10), 6174-6200. Retrieved from https://ojs.unud.ac.id/index.php/Manajemen/article/view/21245/15738

Lathifah, I., \& Rohman, A. (2014). The Influence of Work-Family Conflict on Turnover Intentions with Job Satisfaction as an Intervening Variable on Public Accountant Firms in Indonesia. International Journal of Research in Business and Technology, 5(2), 1-10. Retrieved from http://www.ijrbtonline.com/ index.php/ijrbt/article/view/5.2.342

Lee, N., Zvonkovic, A. M., \& Crawford, D. W. (2013). The Impact of Work-Family Conflict and Facilitation on Women's Perceptions of Role Balance. Journal of Family Issues, 35(9), 1252-1274. https://doi.org/10.1177/0192513X1348 1332

Leisanyane, K., \& Khaola, P. P. (2013). The Influence of Organisational Culture and Job Satisfaction on Intentions to Leave: The Case of Clay Brick Manufacturing Company in Lesotho. Organization for Social Science Research in Eastern and Southern Africa, 29(1), 59-75. Retrieved from https://www.ajol.info/index.php/eassrr/article/view/84320/74323

Moser, C. O. N. (1989). Gender planning in the third world: Meeting practical and strategic gender needs. World Development, 17(11), 1799-1825. https://doi.org/https://doi.org/10.1016/0305-750X(89)90201-5

Nanda, N. L. N., \& Utama, I. W. M. (2015). Pengaruh Konflik-kerja Keluarga dan Kepuasan Kerja Terhadap Tingkat Turnover Intention Karyawan pada Restoran Pizza Hut Mall Bali Galeria. E-Jurnal EP Unud, 4(9), 2461-2477. Retrieved from https://ojs.unud.ac.id/index.php/Manajemen/article/view/ $12879 / 10299$

Ningsih, F. R., \& Arsanti, T. A. (2014). Pengaruh Job Satisfaction terhadap OCB dan Turnover Intention. BENEFIT Jurnal Manajemen Dan Bisnis, 18(1), 4148. Retrieved from http://journals.ums.ac.id/index.php/benefit/article/view/ 1388

Nohe, C., \& Sonntag, K. (2014). Work-Family Conflict, Social Support, and Turnover Intentions: A Longitudinal Study. Journal of Vocational Behavior, 85(1), 1-12. https://doi.org/10.1016/j.jvb.2014.03.007

Ozbag, G. K., \& Ceyhun, G. C. (2014). Does Job Satisfaction Mediate The Relationship Between Work- Family Conflict And Turnover? A Study of 
Turkish Marine Pilots. Procedia - Social and Behavioral Sciences, 140, 643649. https://doi.org/10.1016/j.sbspro.2014.04.485

Paramita, I. G. A., \& Subudi, M. (2017). Pengaruh Konflik Pekerjaan-Keluarga Terhadap Turnover Intention Melalui Mediasi Kepuasan Kerja Pada Hoki Bank Cabang Gatot Subroto. E-Jurnal Manajemen Unud, 6(12), 6441-6470. Retrieved from https://ojs.unud.ac.id/index.php/Manajemen/article/view/ $33694 / 21492$

Putra, I. P. S. S., \& Suana, I. W. (2016). Pengaruh Perceived Organizational Support Dan Komitmen Organisasional Terhadap Turnover Intention Karyawan. EJurnal Manajemen Universitas Udayana; Vol 5 No 10 (2016), 5(10), 62606287. Retrieved from https://ojs.unud.ac.id/index.php/Manajemen/article/ view/22380

Rantika, R., \& Sunjoyo. (2011). Pengaruh Konflik Kerja-Keluarga Terhadap Komitmen Oragnisasi yang Dimediasi oleh Kepuasan Kerja Pada Profesi Perawat di Rumah Sakit Umum Daerah (RSUD) DR. Moewardi Surakarta. Jurnal Manajemen Teori Dan Terapan, 4(2), 28-43. Retrieved from https://ejournal.unair.ac.id/JMTT/article/viewFile/2418/1773

Rathi, N., \& Barath, M. (2013). Work $\square$ family conflict and job and family satisfaction: Moderating effect of social support among police personnel. Equality, Diversity and Inclusion: An International Journal, 32(4), 438-454. https://doi.org/10.1108/EDI-10-2012-0092

Rizwan, M. (2014). Preceding to Employee Satisfaction and Turnover Intention. Internaional Journal of Human Resource Studies, 4(3), 87-106. Retrieved from

http://citeseerx.ist.psu.edu/viewdoc/download?doi=10.1.1.680.5875\&rep=rep $1 \&$ type $=$ pdf

Robbins, S. P., \& Judge, T. A. (2015). Perilaku Organisasi (16th ed.). Jakarta: Salemba Empat.

Robert, K., \& Kinicki, A. (2014). Organizational Behavioral (5th ed.). Boston: McGraw-Hill.

Roboth, J. Y. (2015). Analisis Work Family Conflict Stres Kerja Dan Kinerja Wanita Berperan Ganda Pada Yayasan Compassion East Indonesia. Jurnal Riset Bisnis Dan Manajemen, 3(1), 33-46. Retrieved from https://media.neliti.com/media/publications/127629-ID-analisis-work-familyconflict-stres-kerj.pdf

Saeed, I., Waseem, M., Sikander, S., \& Rizwan, M. (2014). The relationship of Turnover intention with job satisfaction, job performance, Leader member 
exchange , Emotional intelligence and organizational commitment. International Journal of Learning Dan Development, 4(2), 242-256. Retrieved from http://www.macrothink.org/journal/index.php/ijld/article /view/6100/4957

Sakiru, O. K., Silva, J. L. D., Othman, J., Daudsilong, A., \& Busayo, A. T. (2013). Leadership Styles and Job Satisfaction among Employees in Small and Medium Enterprises. International Journal of Business and Management, 8(13), 34-41. https://doi.org/10.5539/ijbm.v8n13p34

Saputra, I. M. A., \& Wibawa, I. M. A. (2018). Pengaruh Kepuasan Kerja, Keadilan Organsasional, dan Pemberdayaan Karyawan Terhadap Komitmen Organisasional Karyawan. E-Jurnal Manajemen Unud, 7(6), 3201-3229. https://doi.org/10.24843/EJMUNUD.2018.v7.i06.p13

Setiawan, R., \& Brian, H. (2013). Pengaruh Komitmen Organisasional Terhadap Kepuasan Kerja Karyawan Paparon's Pizza City Of Tomorrow. Jurnal Studi Manajemen Dan Organisasi, 1(1), 21-41. Retrieved from https://media.neliti.com/media/publications/36244-ID-pengaruh komitmenorganisasional-terhadap-kepuasan-kerja-karyawan-paparons-pizza.pdf

Susanto. (2010). Analisis Pengaruh Konflik Kerja-Keluarga terhadap Kepuasan Kerja Pengusaha Wanita di Kota Semarang. Aset, 12(1), 75-85. Retrieved from https://media.neliti.com/media/publications/36608-ID-analisispengaruh-konflik-kerja-keluarga-terhadap-kepuasan-kerja-pengusahawanit.pdf

Swaminathan, S., \& Jawahar, P. D. (2013). Job Satisfaction as A Predictor of Organizational Citizenship Behavior: An Empirical Study. Global Journal of Business Research, 7(1), 71-80. Retrieved from ftp://ftp.repec.org/opt/ReDIF/ RePEc/ibf/gjbres/gjbr-v7n1-2013/GJBR-V7N1-2013-7.pdf

Tariana, I. W. A., \& Wibawa, I. M. A. (2016). Peran Mediasi Kepuasan Kerja Dalam Pengaruh Work Family Conflict dan Turnover Intention Pada Karyawan Wanita. E-Jurnal Manajemen Unud, 5(9), 5433-5461. Retrieved from https://ojs.unud.ac.id/index.php/Manajemen/article/view/19978/15432

Tett, R. P., \& Meyer, J. P. (1993). Job satisfaction, organizational commitment, turnover intention, and turnover: Path analyses based on meta-analytic findings. Personnel Psychology, 46(2), 259-293. https://doi.org/10.1111/ j.1744-6570.1993.tb00874.x

Waspodo, A. A., Handayani, N. C., \& Paramita, W. (2013). Pengaruh Kepuasan Kerja dan Stres Kerja terhadap Turnover Intention pada Karyawan PT. Unitex di Bogor. Jurnal Riset Manajemen Sains Indonesia (JRMSI), 4(1), 97-115. Retrieved from http://journal.unj.ac.id/unj/index.php/jrmsi/article/view/ $780 / 689$ 
Wibowo. (2012). Manajemen Kinerja (3rd ed.). Jakarta: Raja Grafindo Persada.

Wulandari, I. A. D., \& Dewi, A. I. G. A. (2016). Pengaruh Work-Family Conflict Terhadap Turnover Intention Melalui Mediasi Kepuasan Kerja pada Hotel Grand Inna Kuta. E-Jurnal Manajemen Unud, 5(10), 813-839. Retrieved from https://ojs.unud.ac.id/index.php/Manajemen/article/view/20440/15641

Yeyen, K. (2017). Peran Orientasi Kesuksesan Karier dalam Memediasi Pengaruh Triple Roles Conflict, Fear Of Success, dan Intervensi Pengembangan Karier Terhadap Pengembangan Karier Wanita di Bali. Universitas Udayana.

Yuliana, E. S., \& Yuniasanti, R. (2013). Hubungan Antara Konflik PekerjaanKeluarga dengan Kepuasan Kerja pada Polisi Wanita di POLRES Kulon Progo. Jurnal Sosio Humaniora, 4(5), 62-73. Retrieved from http://ejurnal.mercubuanayogya.ac.id/index.php/soshum/article/view/129/117

Yunita, P. I., \& Kismonto, G. (2014). Influence of Work-Family Conflict on Employees Turnover Intention with Gender, Sosial Support and Individual Values as Moderating Effect. Journal of Indonesian Economy and Business, 29(1), 17-30. Retrieved from https://jurnal.ugm.ac.id/jieb/article/download/ $6210 / 21579$ 